\title{
ANALISIS FAKTOR PEMILIHAN MEDIA SOSIAL LINE DI KALANGAN REMAJA KOTA BANDUNG
}

\author{
Nofia Nandha Rani dan Dini Salmiyah Fithrah Ali \\ Ilmu Komunikasi, Fakultas Komunikasi Bisnis, Universitas Telkom \\ Email : nofianandhaa@gmail.com \\ dinidjohan@gmail.com
}

\begin{abstract}
The increasing of internet usage triggered the growth of social media activity. One of the social media which rose significantly is Line. Three years after Line debut, statistic showed that Line has 470 million users and the application has been downloaded over 1 million times in all over the world.This research is to determine what factors that influence people in Bandung City in deciding to choose social media Line. The theory that used in this research isStimulus Organism Respons Theory.. This research is using a descriptive method to visualize systematically, factually and accuracy regarding facts, characters and relation with the phenomena to be explored. Done by a survey to 180 people of Bandung City which have been chosen through multi-usage cluster sampling technique. Data that has been gathered then handle with using analysis factor method on SPSS 20.This research resulted in three factors which became the factor in choosing social media Line in Bandung area that has been obtained through analysis factor process. Those three factors in sequence are Networking Interactions factor consist of interaction and networking, User Information factor, including information, Social Simulation, User content and Archive factor. The rest another factor that owned by the user in choosing social media Line in Bandung area.
\end{abstract}

Keywords : line, new media, social media, communication, factor analysis

\section{A. PENDAhuluan}

Era ini telah melahirkan internet yang membawa fenomena baru di bidang media komunikasi massa. Sebuah penelitian yang dilakukan di Amerika menunjukan satu di antara tiga warga Amerika Serikat meninggalkan televisi apabila mereka diminta memilih antara internet dan televisi. Survei Media Research Internet Study (Jawa Pos, 2001:1).menyatakan 41\% orang lebih memilih internet daripada televisi. Hal ini membuktikan bahwa pengaruh pertumbuhan internet di zaman teknologi seperti sekarang ini memiliki pengaruh besar bagi kehidupan.

Awal dekade 1990-an teknologi Internet masih terbilang asing untuk sebagian besar masyarakat Indonesia. Saat itu, Internet hanya dapat diakses oleh segelintir orang karena untuk mengakses Internet dibutuhkan biaya yang tidak sedikit ditambah minimnya jumlah pengguna personal komputer atau pc. Sejalan bergulirnya waktu, aksesibilitas teknologi Internet menjadi semakin luas dan mudah. Menurut data yang dilansir Asosiasi Penyelenggara Jasa Internet 
Indonesia (APJII), sampai awal tahun 2009 tercatat sekitar 25 juta pengguna Internet. Kedepannya angka ini akan meningkat tajam karena APJII menghitung bahwa pengguna Internet meningkat 25 persen per tahun. (Gumilar,Jurnal Kajian Komunikasi, Volume 2, No. 1, Juni 2014 hlm 85-92).

Menggunakan jejaring sosial
Mencari info/searching/browsing
Instant messaging
Mencari berita terkini
Video streaming Download/Upload Video
Berkomunikasi menggunakan Email
Jual Beli online
Game online Video Call
Forum online/komunitas online

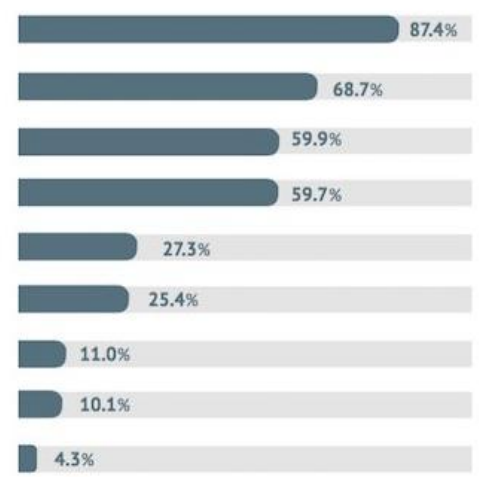

(Sumber: Ansari; 2014)

Dari Gambar 1 dapat dilihat bahwa penggunaan internet paling banyak di Indonesia adalah untuk mengakses situs jejaring sosial. Menurut Chris Brogan (2010: 11) dalam bukunya yang berjudul Social Media 101 Tactic and Tips to Develop Your Business Online mendefinisikan sosial media sebagai berikut:

"Social media is a new set of communication and collaboration tools that enable many types of interactions that were previously not available to the common person".

Berdasarkan definisi tersebut media sosial dapat diartikan sebagai salah satu set baru komunikasi dan alat kolaborasi yang memungkinkan banyak jenis interaksi yang sebelumnya tidak tersedia untuk orang biasa.Berdasarkan hasil riset jumlah pengguna dari masing-masing aplikasi tersebut menunjukkan bahwa Line memiliki pertumbuhan paling pesat dan populer dibanding kedua pesaingnya.

Selain itu, peneliti juga membandingkan ketiga aplikasi tersebut berdasarkan fitur, sebagai berikut:

Tabel 1 Perbandingan Fitur antara WhatsApp, Line dan BBM

\begin{tabular}{|l|c|c|c|}
\hline \multicolumn{1}{|c|}{ Fitur } & WhatsApp & Line & BBM \\
\hline Video Call & no & yes & no \\
\hline Free Call & yes & yes & yes \\
\hline
\end{tabular}


Nofia, Dini [Analisis Faktor Pemilihan Media Sosial Line di Kalangan Remaja...]

\begin{tabular}{|l|c|c|c|}
\hline Status Pesan (terkirim,terbaca,gagal) & yes & yes & yes \\
\hline Group Chat & $15-30$ members & 100 members & 30 members \\
\hline Broadcast messages & yes & yes & yes \\
\hline Fitur Find & yes & yes & yes \\
\hline Add Friend with QR code & no & yes & yes \\
\hline $\begin{array}{l}\text { Sticker emotion (emotion yang berbentuk } \\
\text { sticker) }\end{array}$ & no & yes & no \\
\hline $\begin{array}{l}\text { Shake (menggoyangkan smarthphone untuk } \\
\text { mencari teman) }\end{array}$ & no & yes & yes \\
\hline Share multimedia & yes & yes & yes \\
\hline Voice chat & yos & yes & yes \\
\hline Timeline & no & & \\
\hline
\end{tabular}

(Sumber: olahan peneliti, 2015)

Berdasarkan tabel 1 terlihat bahwa aplikasi Line memiliki fitur yang lebih menarik dan lengkap dibandingkan dengan WhatsApp dan BBM. Hal inilah yang membuat Line lebih unggul menarik hati konsumennya. Berdasarkan riset yang dilakukan oleh APJII (Asosiasi Penyelenggara Jasa Internet Indonesia), penggunaan internet paling banyak di Indonesia adalah untuk mengakses situs jejaring sosial. Jejaring sosial yang banyak diminati pada saat ini salah satunya adalah Line dengan 470 juta orang lebih pengguna di seluruh dunia di awal 3 tahun kemunculannya, dibandingkan dengan pesaingnya seperti WhatsApp yang membutuhkan waktu lima tahun untuk meraih 600 juta pengguna di dunia dan BBM meraih 91 juta pengguna selama 10 tahun dari tahun 2006 hingga 2014. Selain itu, Line pun memiliki fitur yang lebih banyak dan beragam dibanding kedua pesaingnya tersebut.

Pada sebuah riset yang dilakukan Head of Digital Business Unit Dwi Sapta Group Chandra Marsono, terungkap beberapa trend penggunaan platform media sosial di Indonesia. Riset ini melibatkan 3.891 responden yang berasal dari berbagai daerah di tanah air, daerah Jawa tercatat menyumbangkan persentase terbanyak. Usia dan jenis kelamin koresponden menjadi indikator yang kemudian membentuk lima kelompok pengguna media sosial sebagai berikut. 


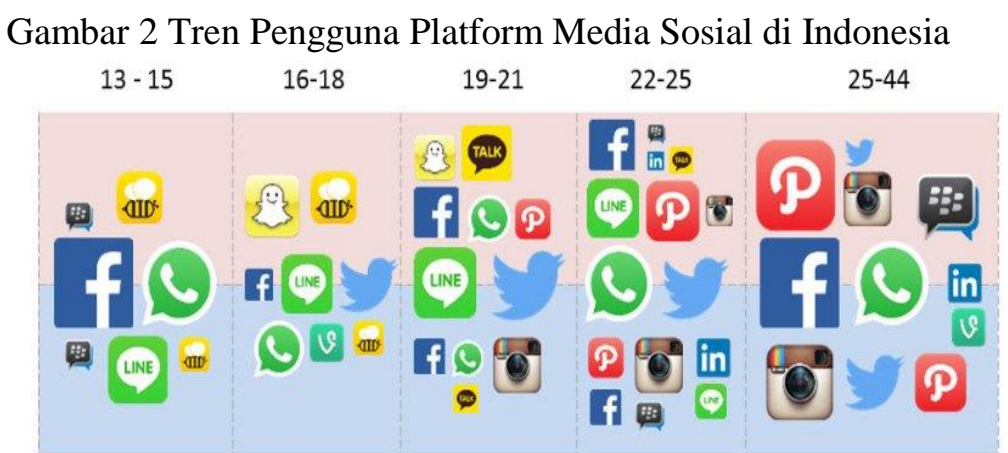

(Sumber : marsono; 2015)

Gambar 2 menunjukkan bahwa pengguna di rentang usia 19-21 cenderung memilih LINE dan Twitter, dengan berbagai faktor kebutuhan berbeda masing-masing individu. Selanjutnya APJII juga menunjukkan bahwa jumlah pengguna internet di Indonesia mencapai 88 juta orang hingga akhir tahun 2014. Berdasarkan populasi pengguna internet terbanyak adalah provinsi Jawa Barat sebanyak 16.4 juta.

Maka dari itu, peneliti ingin mengetahui faktor-faktor apa saja yang menjadi alasan remaja memilih media sosial Line di wilayah Bandung dengan menggunakan metode analisis faktor. Terpilihnya kota Bandung sebagai wilayah objek penelitian didasari karena Bandung menjadi kota terbanyak pengguna media sosial di daerah Jawa Barat dan dengan respondennya adalah remaja Kota Bandung yang berusia 19-21 tahun. Judul dari penelitian ini adalah "Analisis Faktor Pemilihan Media Sosial Line" dengan respondennya adalah remaja Kota Bandung yang berusia 19-21 tahun.

Berdasarkan latar belakang yang telah diuraikan di atas, peneliti mengidentifikasi permasalahan dalam penelitian ini faktor-faktor apa saja yang mempengaruhi keputusan remaja Bandung dalam memilih media sosial Line? Berdasarkan identifikasi permasalahan di atas, maka penelitian ini bertujuan untuk untuk mengetahui faktor-faktor apa saja yang mempengaruhi keputusan masyarakat Bandung dalam memilih media sosial Line.

\section{B. METODE PENELITIAN}

Dalam penelitian ini, Peneliti menggunakan metode deskriptif. Metode deskriptif adalah suatu metode yang digunakan untuk menjelaskan karakteristik sekelompok manusia, suatu objek, suatu set kondisi, suatu sistem pemikiran ataupun suatu kelas peristiwa pada masa sekarang (Sekaran, 2006: 158). Tujuan dari penelitian deskriptif adalah untuk membuat deskripsi, gambaran atau lukisan secara sistematis, faktual dan akurat mengenai fakta-fakta, sifat-sifat serta 
hubungan antarfenomena yang diselidiki. Penulis akan mendeskripsikan mengenai faktor pemilihan media sosial Line. Untuk penelitian lebih lanjut, analisis dilakukan dengan menggunakan metode analisis kuantitatif. Metode kuantitatif adalah metode penelitian yang untuk meneliti pada populasi dan sampel tertentu, pengumpulan data menggunakan instrumen penelitian, analisis data bersifat kuantitatif/statistik, dengan tujuan untuk menguji hipotesis yang telah ditetapkan (Sugiyono, 2012: 7).

Subjek penelitian menurut Arikunto (2006: 130) adalah benda, hal atau orang di mana tempat variabel penelitian melekat. Subjek dalam penelitian ini adalah masyarakat Kota Bandung yang berusia 19-21 tahun. Objek penelitian menurut Sugiyono (2012: 38) adalah suatu atribut atau sifat atau nilai dari orang, objek atau kegiatan yang mempunyai variasi tertentu yang ditetapkan oleh peneliti untuk dipelajari dan kemudian ditarik kesimpulannya. Adapun objek dalam penelitian ini adalah faktor pemilihan media sosial berdasarkan karakteristik dari media sosial yaitu jaringan, informasi, arsip, interaksi, simulasi sosial dan konten oleh pengguna.

Skala yang digunakan dalam penelitian ini adalah skala ordinal. Data berskala ordinal sudah menunjukan ada tingkatan atau peringkat, berupa kategori-kategori untuk menunjukan kategori yang satu lebih baik dari kategori yang lain, tetapi jarak antarmasing-masing kategori tidak sama. Skala yang digunakan dalam penelitian ini adalah skala ordinal. Data berskala ordinal sudah menunjukan ada tingkatan atau peringkat, berupa kategori-kategori untuk menunjukan kategori yang satu lebih baik dari kategori yang lain,tetapi jarak antar masing-masing kategori tidak sama (Mulyatiningsih, 2012: 34).

Pilihan jawaban untuk kuesioner penelitian yang berbentuk kalimat positif dalam penelitian ini adalah:

5 = Sangat Setuju (SS), 4 = Setuju (S), 3 = Kurang Setuju (KS), 2 = Tidak Setuju (TS) dan 1 = Sangat Tidak Setuju (STS).

Tahapan-tahapan yang dilakukan penulis dalam melakukan penelitian ini digambarkan dalam tahapan sebagai berikut. 


\section{Gambar 3 Tahapan Penelitian}

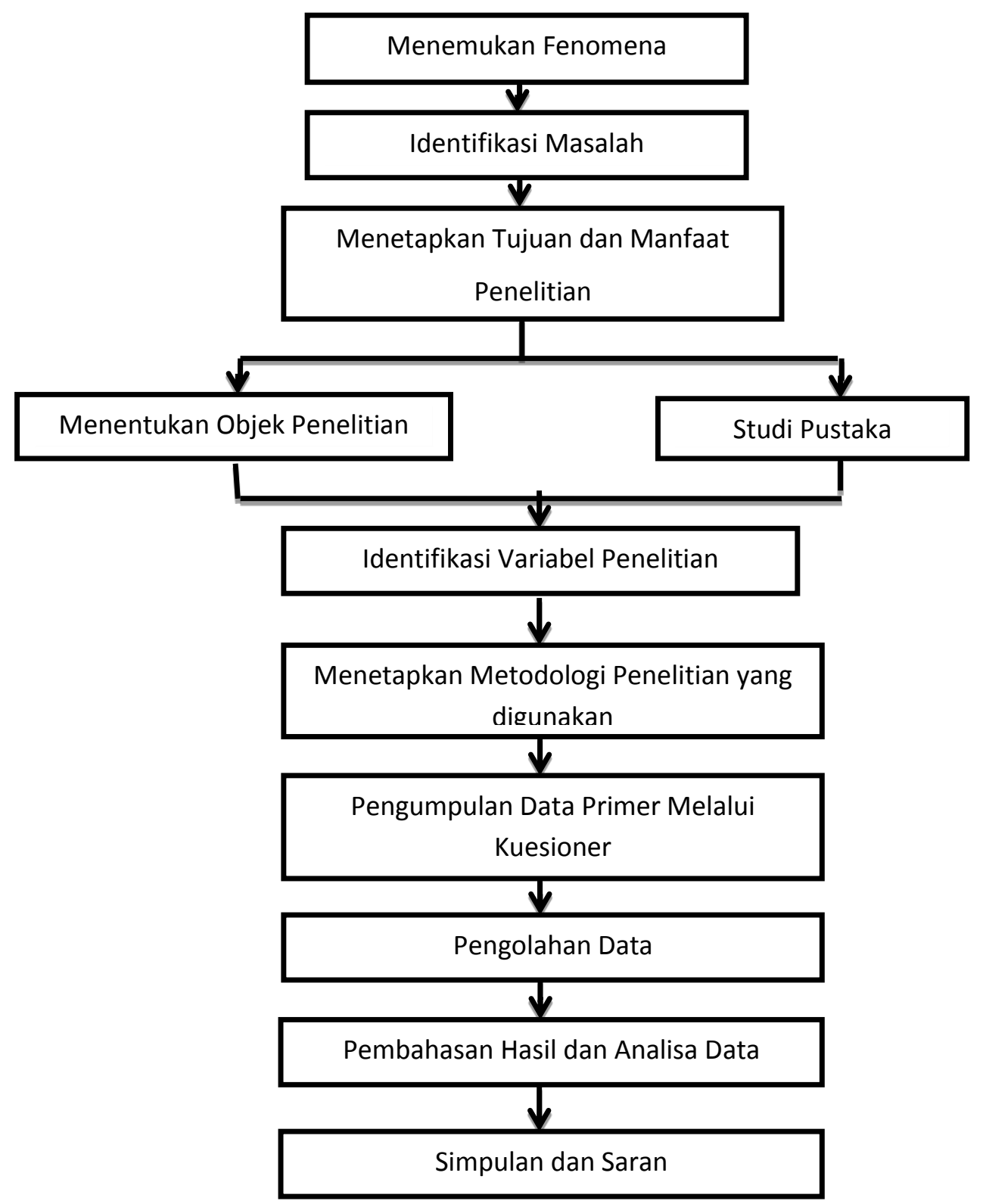

Populasi dalam penelitian ini adalah seluruh masyarakat Kota Bandung. Menurut data yang diperoleh dari Dinas Kependudukan Kota Bandung 2015, jumlah penduduk kota Bandung adalah 2.748.733 orang. Jumlah tersebut sangat banyak untuk dilakukan penelitian, maka dari itu peneliti menggunakan Teknik Multistage Cluster untuk menarik sejumlah sampel. 
Teknik Multistage Cluster Sampling yaitu populasi dibagi atas kelompok berdasarkan area atau cluster, kemudian beberapa cluster dipilih sebagai sampel (Siregar, 2013: 132). Dalam penelitian ini tahapan cluster dilakukan beberapa kali, yaitu:

Pada tahap pertama, Kota Bandung dibagai menjadi enam wilayah berdasarkan geografisnya yaitu, wilayah Bojonagara, Cibeunying, Tegallega, Karees, Ujung Berung, dan Gedebage. Tahap kedua, yaitu memilih satu kecamatan dari tiap wilayah tersebut secara random.

Tabel 2 Data Populasi Dari Masing-masing Cluster

\begin{tabular}{|c|c|c|c|c|c|}
\hline No & Wilayah & Kecamatan & Kelurahan & RT & Jumlah \\
\hline 1 & Bojonagara & Cicendo & Pasirkaliki & 09 & 230 \\
\hline 2 & Cibeunying & Sumur Bandung & Braga & 06 & 180 \\
\hline 3 & Karees & Lengkong & Cijagra & 01 & 240 \\
\hline 4 & Tegallega & Bojongloa Kidul & Cibaduyut & 02 & 300 \\
\hline 5 & Ujung Berung & Cibiru & Cipadung & 03 & 330 \\
\hline 6 & Gedebage & Bandung Kidul & Mengger & 03 & 202 \\
\hline 7 & \multicolumn{2}{|c|}{ Total } & & 1482 \\
\hline
\end{tabular}

(Sumber: Olahan Data Penulis, 2015)

Teknik penarikan sampel pada penelitian ini menggunakan Teknik Multistage Cluster Sampling yang menghasilkan populasi sebesar 1482 orang. Kemudian peneliti menentukan ukuran sampel dengan menggunakan Rumus Taro Yamane, karena jumlah populasi sudah diketahui. Menurut Riduwan; 2010) penentuan jumlah sampel yang populasinya sudah diketahui dapat dilakukan dengan menggunakan rumus dari Taro Yamane sebagai berikut :

$$
n=\frac{N}{N \cdot d^{2} \cdot+1}
$$

Dimana:

$\mathrm{n}=$ jumlah sampel

$\mathrm{N}=$ jumlah populasi

$\mathrm{d}=$ presisi yang ditetapkan 
Berdasarkan rumus tersebut, perhitungan jumlah sampel menggunakan tingkat presisi yang ditetapkan. Presisi ini digunakan untuk menentukan tingkat keakuratan hasil penelitian yang diinginkan.

"Presisi adalah tingkat ketetapan yang ditentukan oleh perbedaan hasil yang diperoleh dari sampel dibandingkan hasil yang diperoleh dari catatan lengkap, dengan syarat bahwa keadaan-keadaan dimana kedua metode dilakukan, seperti daftar pertanyaan, teknik wawancara, kualitas pencacah dan sebagainya adalah sama" (Singarimbun Masri \& Sofian Effendi, 1995: 149-150).

Batas kesalahan yang ditolerir ini untuk setiap populasi tidak sama, normalnya berkisar antara $1 \%$ hingga $10 \%$. Dalam penelitian ini peneliti menggunakan tingkat presisi $7 \%$ karena dilihat dari banyaknya jumlah populasi. Maka diperoleh jumlah sampel penelitian sebagai berikut:

$$
\begin{aligned}
& \mathrm{n}=1482 \\
& (1482) \cdot(0,07)^{2}+1 \\
& \mathrm{n}=1482 \\
& 8,2618 \\
& \mathrm{n}=179,37 \\
& \mathrm{n}=180 \text { orang }
\end{aligned}
$$

Berdasarkan rumus tersebut, maka jumlah responden dalam penelitian ini adalah 180 orang. Peneliti juga menggunakan kriteria tertentu pada responden agar data responden yang diperoleh sesuai dengan yang diinginkan. Hal ini dikarenakan sifat responden yang cenderung heterogen. Kriteria tersebut adalah:

a) Berusia 19-21 tahun

b) Menggunakan media sosial Line

\section{HASIL DAN PEMBAHASAN}

Penelitian dilakukan dengan metode survei. Peneliti menyebarkan sebanyak 180 kuesioner yang dilakukan dengan cara membagikan kuesioner secara langsung ke responden.

Penelitian ini menggunakan pendapat kalangan remaja masyarak Kota Bandung sebanyak 180 orang yang menggunakan media sosial Line dengan kurun waktu di atas enam bulan. Hasil pengisisan kuesioner oleh responden menunjukkan bahwa terdapat beberapa karakteristik 
mengenai responden antara lain berdasarkan: kelompok usia, jenis kelamin, alamat responden, dan pekerjaan responden.

\section{KMO dan Barlett's Test of Sphericity}

Langkah yang dilakukan setelah mengubah data ordinal menjadi data interval hasil dari kuesioner yang disebar pada 180 orang diperoleh, kemudian data tersebut dianalisis dan diperoleh, yaitu pengujian kecukupan sampel melalui indeks Kaiser Meyer-Olkin (KMO) Measure of Sampling Adequacy dan nilai signifikansi Bartlett's Test of Sphericity. Indeks ini digunakan untuk meneliti ketepatan penggunaan analisis faktor. Apabila nilai KMO antara 0,5 sampai 1 dan signifikansi Bartlett's Test of Sphericity ini kurang dari level signifikansi $(\alpha)$ yang digunakan dapat diartikan bahwa analisis faktor tepat digunakan. (https://jurnal.usu.ac.id/index.php/smatematika/article/download/2208/pdf)

Total variabel faktor yang digunakan dalam penelitian ini adalahenam variabel, yang tertuang dalam 17 pernyataan dalam kuesioner. Seluruh variabel yang diteliti dilakukan input ke dalam SPSS diikuti data yang diperoleh.

\section{Gambar 8 KMO and Barlett's Test of Sphericity}

Kaiser-Meyer-Olkin Measure of Sampling Adequacy.

Bartlett's Test of Sphericity

Df

Sig.

(sumber: olahan data SPSS)

Gambar 8 menunjukan angka KMO Measure of Sampling Adequacy (MSA) adalah 0,617. Angka MSA yang lebih besar dari 0,5dapat diartikan bahwa kumpulan variabel faktorfaktor tersebut dapat diproses lebih lanjut menggunakan analisis faktor. Dapat juga dilihat angka Barlett's Test of Sphericity (diperlihatkan dengan angka Chi Square) sebesar 598.771 dengan signifikansi 0,000 yang artinya dapat dipercaya 100\% bahwa antarvariabel terdapat korelasi. Nilai signifikansi kurang dari 0,05 $(0,000<0,05)$, maka variabel yang ada sebenarnya sudah bisa dianalisis lebih lanjut.

\section{Anti Image}

Dari pengolahan data tersebut juga diperoleh Anti Image Matrices untuk melihat korelasi antarvariabel independen dapat diperhatikan tabel Anti-Image Matrices. Nilai yang diperhatikan 
adalah MSA (Measure of Sampling Adequacy). Nilai MSA berkisar antara 0 hingga 1. (http://ejournal.upi.edu/index.php/jmee/article/download/9627/5936)

Tabel 3 Anti Image Matrices

\begin{tabular}{|c|l|c|}
\hline No. & \multicolumn{1}{|c|}{ Faktor-faktor } & MSA \\
\hline 1 & Jaringan & 0,590 \\
\hline 2 & Informasi & 0,501 \\
\hline 3 & Arsip & 0,580 \\
\hline 4 & Interaksi & 0,743 \\
\hline 5 & Simulasi Sosial & 0,643 \\
\hline 6 & Konten oleh Pengguna & 0,647 \\
\hline
\end{tabular}

(sumber: olahan data peneliti,2016)

Tabel 3 menunjukan nilai MSA dari masing-masing variabel dimana variabel tersebut didapat berdasarkan karakteristik dari media sosial selanjutnya variabel tersebut akan diolah dan diletakkan pada faktor baru yang membentuknya. Faktor-faktor tersebut dapat dikatakan sebagai faktor pendorong pemilihan media sosial Line apabila nilai MSA untuk setiap faktor adalah lebih besar dari 0,5. Dari masing-masing nilai MSA yang terlihat dalam tabel 3 menunjukan tidak ada faktor yang memiliki nilai MSA $\leq 0,5$. Artinya enam faktor tersebut dapat dikatakan sebagai faktor pendorong pemilihan media sosial Line pada wilayah Bandung, sehingga tidak perlu dilakukan analisis ulang dan dapat langsung melanjutkan analisis ke langkah berikutnya.

\section{Proses Factoring}

Setelah variabel ditentukan dan dipilih serta perhitungan korelasinya telah memenuhi persyaratan untuk dilakukan analisis, langkah selanjutnya adalah membentuk faktor untuk menemukan struktur yang mendasari hubungan antarvariabel awal tersebut. Metode yang digunakan dalam pembentukan faktor adalah metode analisis principal component. Dua langkah utama dalam pembentukan faktor adalah penentuan jumlah faktor dan rotasi faktor-faktor yang terbentuk. 
(http://eprints.uny.ac.id/12575/1/Skripsi_Analisis_Faktor_Wiratmanto_07305144044.pdf)

Dalam menentukan faktor baru, dapat dilakukan dengan melihat eigenvalue.

Penelitian ini menggunakan Principal Component Analysis dimana menggunakan total variance atau ketiga jenis varian, menghasilkan specific, dan error variance terkecil. Guna menentukan seberapa banyak faktor yang mungkin terbentuk dapat dilihat pada tabel Total Variance Explained sebagai berikut: (Santoso, 2006: 42-3).

Tabel 4 Total Variance Explained

\begin{tabular}{|c|c|c|c|c|c|c|c|c|c|}
\hline \multirow[t]{2}{*}{ Comp. } & \multicolumn{3}{|c|}{ Initial Eigenvalues } & \multicolumn{3}{|c|}{ Extraction Sums of Squared Loadings } & \multicolumn{3}{|c|}{ Rotation Sums of Squared Loadings } \\
\hline & Total & $\begin{array}{c}\% \text { of } \\
\text { Variance }\end{array}$ & Cumulative $\%$ & Total & $\%$ of Variance & Cumulative $\%$ & Total & $\begin{array}{c}\% \text { of } \\
\text { Variance }\end{array}$ & Cumulative $\%$ \\
\hline $\mathbf{1}$ & 2,985 & 49,744 & 49,744 & 2,985 & 49,744 & 49,744 & 2,923 & 48,720 & 48,720 \\
\hline 2 & 1,091 & 18,191 & 67,935 & 1,091 & 18,191 & 67,935 & 1,130 & 18,829 & 67,548 \\
\hline 3 & 1,071 & 17,852 & 85,787 & 1,071 & 17,852 & 85,787 & 1,094 & 18,239 & 85,787 \\
\hline 4 & ,513 & 8,553 & 94,341 & & & & & & \\
\hline 5 &, 271 & 4,510 & 98,851 & & & & & & \\
\hline 6 & 069 & 1,149 & 100,000 & & & & & & \\
\hline
\end{tabular}

(sumber: olahan data peneliti, 2016)

Jumlah faktor yang akan dibentuk ditentukan dengan melakukan kombinasi beberapa kriteria untuk mendapatkan jumlah faktor yang paling sesuai dengan data penelitian. Kriteria pertama yang digunakan adalah nilai eigen. Faktor yang mempunyai nilai eigen lebih dari satu akan dipertahankan dan faktor yang mempunyai nilai eigen kurang dari satu tidak akan diikutsertakan dalam model. Dari tabel diatas diperoleh nilai eigen yang lebih besar dari satu pada 1 faktor, 2 faktor dan 3 faktor. Dengan kriteria ini diperoleh jumlah faktor yang digunakan adalah 3 faktor.

Kriteria kedua adalah penentuan berdasarkan nilai persentase variansi total yang dapat dijelaskan oleh banyaknya faktor yang akan dibentuk. Dari tabel diatas dapat dilakukan interpretasi yang berkaitan dengan variansi total kumulatif sampel. Jika variabel-variabel itu diringkas menjadi beberapa faktor, maka nilai total variansi yang dapat dijelaskan adala sebagai berikut. (http://journal.uim.ac.id/index.php/Zeta/article/download/6/23) 
Component $1: 2,985 / 6 \times 100 \%=49,75 \%$

Component $2: 1,091 / 6 \times 100 \%=18,183 \%$

Component $3: 1,071 / 6 \times 100 \%=17,85 \%$

Dengan mengekstraksi variabel-variabel awal menjadi 3 faktor telah dihasilkan variansi total kumulatif yang cukup besar yaitu 85,783\%, artinya dari 3 faktor yang terbentuk sudah dapat mewakili 6 variabel pemilihan media sosial Line yang menjelaskan kira - kira sebesar 85,783\%. Dengan demikian ekstraksi 3 faktor yang diperoleh telah dapat dihentikan dan telah memenuhi kriteria kedua.

\section{Pengelompokan Faktor}

Setelah diketahui bahwa tiga faktor adalah jumlah yang paling optimal, maka tabel component matriks menunjukkan distribusi keenam variabel tersebut pada tiga faktor yang terbentuk sedangkan angka-angka yang ada pada tabel tersebut adalah factor loadings, yang menunjukkan besar korelasi antara suatu variabel dengan faktor 1, 2, dan 3. Rotasi faktor dilakukan untuk membuat nilai korelasi yang besar menjadi semakin besar, dan nilai korelasi yang kecil menjadi semakin kecil, sehingga perbedaan nilai korelasi akan semakin jelas setelah dilakukan rotasi faktor. Rotasi faktor ini diperlukan jika metode ekstraksi faktor belum menghasilkan komponen faktor utama yang jelas. Tujuan dari rotasi faktor ini agar dapat memperoleh struktur faktor yang lebih sederhana agar mudah diinterpretasikan.Rotasi yang digunakan dalam penelitian ini adalah rotasi Varimax yaitu metode rotasi orthogonal untuk meminimalisasi jumlah indikator yang mempunyai faktor loading tinggi pada tiap faktor.

Tabel 5 Rotated Component Matrix ${ }^{a}$

\begin{tabular}{|c|c|c|c|}
\hline & \multicolumn{3}{|c|}{ Component } \\
\hline & 1 & 2 & 3 \\
\hline X3 & ,464 & 337 & ,796 \\
\hline $\mathrm{X} 4$ & ,860 &, 322 &, 359 \\
\hline $\mathrm{X} 5$ & ,463 &, 818 & ,308 \\
\hline $\mathrm{X} 1$ & ,891 & ,443 &, 342 \\
\hline $\mathrm{X} 2$ &,- 340 &, 851 &, 325 \\
\hline X6 &, 323 & 802 &,- 363 \\
\hline
\end{tabular}

(sumber: olahan data peneliti,2016) 
Tabel 5 menunjukan component matrix setelah dilakukan rotasi. Perbedaan nilai korelasi tiap variabel awal menjadi semakin jelas, sehingga tiap variabel awal dapat dimasukan ke dalam faktor 1, 2 atau 3. Untuk penentuan variabel apa saja yang akan masuk ke dalam faktor 1, 2 atau 3 yaitu dengan melihat nilai faktor loading $>0,5$ pada tiap component.

Hasil penelitian ini menunjukkan bahwa terdapat tiga faktor yang terekstrasi atau terbentuk dari proses analisis faktor. Ketiga faktor tersebut antara lain Jaringan Interaksi, Informasi Pengguna, dan Arsip. Interpretasi nama faktor dilakukan dengan judgment namun mengacu pada teori. Dikarenakan sifatnya yang subjektif, hasil bisa berbeda jika interpretasi dilakukan oleh orang lain. Faktor yang terbentuk dapat digunakan sebagai variabel baru menggantikan variabel-variabel asli yang dilihat dari faktor loading paling tertinggi. Berikut ini ialah pembahasan mengenai setiap faktor yang terbentuk :

1) Jaringan Interaksi

Berdasarkan nilai-nilai pada tabel 4.3 diketahui bahwa faktor Jaringan Interaksi memiliki nilai \% of variance tertinggi yakni 49,744\% dengan eigenvalue sebesar 2,985 yang mencakup dua variable, antara lain: Jaringan $(0,891)$ dan Interaksi $(0,860)$. Faktor Jaringan Interaksi ini menjadi faktor pendorong utama dalam memilih media sosial Line dengan nilai \% of variance tertinggi.

Pada media sosial Line, pengguna dapat membentuk jaringan komunitas atau grup yang dapat diikuti oleh lebih dari 200 pengguna, selain itu Line pun memberikan kemudahan dalam hal mencari teman atau menambahkan teman untuk membangun jaringan tersebut seperti adanya fitur $Q R$ code, menggunakan $i d$, fitur shake untuk mencari teman. Melalui fitur-fitur tersebut, Line memberi kemudahan pengguna untuk dapat menjangkau pengguna secara global dan melakukan interaksi. Line memberikan keragaman bentuk interaksi antar pengguna selain dengan bercakap-cakap pada ruang obrol, interaksi pun dapat dilakukan dengan mengomentari status pengguna lain ataupun informasi yang di bagikan pada timeline Line dan dapat pula berupa dengan cara "like" dengan menggunakan emoticon yang disediakan. Oleh karena itu, responden menyatakan bahwa faktor Jaringan Interaksi menjadi faktor pendorong utama pemilihan media sosial Line.

2) Informasi Pengguna

Berdasarkan nilai-nilai pada tabel 4.3 diketahui bahwa faktor Informasi Pengguna memiliki nilai \% of variance tertinggi kedua yakni 18,191\% dengan eigenvalue sebesar 
1,091 yang mencakup tiga variable, antara lain: Informasi $(0,851)$, Simulasi sosial $(0,818)$ dan konten oleh pengguna $(0,802)$. Faktor Informasi Pengguna ini menjadi faktor pendorong kedua dalam memilih media sosial Line pada wilayah Bandung.

Dalam hal membagi informasi, Line menyediakan fitur timeline, timeline disini berisi informasi yang di upload dan di bagikan oleh teman sesama pengguna Line dan akan muncul pada timeline Line tersebut. Selain informasi dari teman, informasi dari accountaccount official tertentu pun di bagikan melalui timeline seperti account official Starbucks dengan informasi promo-promo menarik di Starbucks dan informasi lainlainnya. Hal ini menjadi kesenangan tersendiri bagi pengguna media sosial Line dan menjadi faktor pendorong kedua dalam pemilihan media sosial Line di wilayah Bandung.

3) Arsip

Berdasarkan nilai-nilai pada tabel 4.3 diketahui bahwa faktor Arsip memiliki nilai \% of variance, 17,852\% dengan eigenvalue sebesar 1,071. Faktor Arsip memiliki satu variabel pembentuk didalamnya yaitu variabel Arsip $(0,796)$.Faktor ini menjadi faktor pendorong ketiga dalam memilih media sosial Line pada wilayah Bandung.

Media sosial Line menyediakan fitur Arsip. Bagi pengguna media sosial, arsip menjadi sebuah karakter yang menjelaskan bahwa data atau file yang diunggah telah tersimpan dan dapat diakses kapan pun dan melalui perangkat apa pun. Data yang dapat disimpan di dalam arsip pada media sosial Line diantaranya data gambar, file-file document, video, voice notes, notes, musik, dan lain-lain yang dapat diakses kapanpun ketika dibutuhkan.

\section{KESIMPULAN}

1) Faktor Jaringan Interaksi memiliki eigenvalue (penggambaran jumlah variansi yang diteruskan oleh sebuah faktor) terbesar dan persentase varian (kontribusi) tertinggi. Faktor Jaringan Interaksi mencakup dua variable, yaitu: Jaringan dan Interaksi.

2) Faktor Informasi Pengguna memiliki eigenvalue menengah dan persentase varian (kontribusi) sedang. Faktor Informasi Pengguna yang mencakup tiga variable, antara lain: Informasi, Simulasi Sosial dan Konten oleh Pengguna.

3) Faktor Arsip memiliki eigenvalue sebesar terkecil dan persentase varian (kontribusi) paling rendah. Faktor Arsip memiliki satu variabel yaitu variabel Arsip.

Dari hasil penelitian, ketiga faktor tersebut memiliki persentase varian di atas $60 \%$ yang menunjukkan jumlah variasi yang berhubungan pada suatu faktor yang dinyatakan dalam 
persentase. Hal ini dapat menjelaskan seluruh faktor asli atau variable awal, juga terdapat faktor lain dimiliki oleh pengguna Line dalam pemilihan media sosial Line pada wilayah Bandung.

\section{DAFTAR PUSTAKA}

Arikunto, S. (2016). Prosedur Penelitian Suatu Pendekatan Praktik. Jakarta: Rineka Cipta.

Bogan, Chris. 2010. Social Media 101 Tactics and Tips to Develop Your Business Online. Hobogen : John Wiley \& Sons.

Effendy, Onong Uchjana. 2004. Ilmu Komunikasi Teori dan Praktek. Bandung: Rosdakarya.

Hair, et al. 2006. Multivariate Data Analysis $6^{\text {th }}$ ed. New Jersey: Persey Education.

Jonathan Sarwono, 2012. Path Analysis dengan SPSS, Penerbit PT Elex Media Komputindo.

Mulyatiningsih, Endang.Metode Penelitian Terapan Bidang Pendidikan,( Bandung: Alfabeta, 2012),

Riduwan. (2010). Skala Pengukuran Variabel-variabel Penelitian. Bandung: Alfabeta.

Rumini, Sri dan Siti Sundari. 2004. Perkembangan Anak dan Remaja. PT Rineka Cipta, Jakarta.

Santoso, Singgih. Seri Solusi Bisnis Berbasis TI: Menggunakan SPSS untuk Statistik Multivariat. Jakarta: Elex Media Komputindo, 2006.

Sekaran, Uma. (2006). Metode Penelitian Untuk Bisnis, Edisi keempat. Jakarta: Salemba.

Siregar, Syofian. 2013. Statistik Parametrik untuk Penelitian Kuantitatif. Jakarta. PT. Bumi Aksara

Sugiyono.2012.Metode Penelitian Pendidikan.Bandung: CV Alfabeta.

Singarimbun, Masri \& Sofian Effendi. (1995). Metode Penelitian Survei. Jakarta: PT Pustaka LP3ES.

\section{Jurnal}

https://dailysocial.id/post/penggunaan-media-sosial-di-indonesia-mulai-tersegmentasiberdasarkan-kebutuhan https://jurnal.usu.ac.id/index.php/smatematika/article/download/2208/pdf http://ejournal.upi.edu/index.php/jmee/article/download/9627/5936 http://eprints.uny.ac.id/12575/1/Skripsi_Analisis_Faktor_Wiratmanto_07305144044.pdf http://journal.uim.ac.id/index.php/Zeta/article/download/6/23 Jurnal Kajian Komunikasi, Volume 2, No. 1, Juni 2014 hlm 85-92) 